\title{
Milestones in the Foundation and Role of the Most Significant International Organizations against Money Laundering in the European Union
}

\author{
Attila BUGYÁKI ${ }^{1}$
}

In this two-piece study, the author introduces the most important international organizations and institutions fighting against money laundering of our time, through the main chapters of the formation of the international institutional system. The first part is focused on the creation of the international institutional system fighting against money laundering.

By the $21^{\text {st }}$ century the phenomenon of money laundering-with the need of the laundering of gradually increasing "dirty" money, mainly from drugs, weapons and human trafficking, prostitution and corruption-has become a worldwide problem. With the increasing organization of international criminal groups - taking advantage of the free movement of money and financial servicesare using more and more refined techniques to get more profits with their illegal activities. Money laundering will not leave terrorism untouched - casting a shadow on our everyday life - as particular radical groups use every means necessary to lay their hands on money sources anonymously needed for their existence, as it supplies their destructive actions; and naturally procuring this money the best sources are the money laundered by criminals. Recognising the money laundering and the negative and destructive effects of new crimes on everyday economic, financial and political life based on laundering, the leading countries of the world started international legislation against money laundering and terrorism which laws and codes are strictly regulating the different financial and bank supervision of the nation states. Despite the onsetting difficulties and indecisiveness, it was clear for the European Union that only strong international collaboration-and the unified understanding of measures - is the only power to stop the spread of money laundering. ${ }^{2}$

Keywords: money laundering, fianancing of terrorism, international organizations

Ph.D. student, National University of Public Service, Doctoral School of Military Sciences; e-mail: attila. bugyaki@freemail.hu

2 Initially, not even the countries of the EU could come to an agreement concerning the directives to be made-never mind internationl collaboration-as the lobby activities of different professions (lawyers, notaries) prevented to be included with the announced ones, fearing it would harm their confidentiality obligations. [2: 31] 


\section{Milestones in the Foundation of International Institutions against Money Laundering}

Over the decades several radical opinions have formed about the role of international organizations and institutions. According one opinion the international institutions are the precursors of the world government, which stand up with unified sanctions in conflicts, requisitioning their organized executor apparatus. [1: 25] This idea seems negated, as today the dominance of sovereign countries is felt significantly, preferring their own national economy through their protectionist attitude. Other-negative-opinions say that the activities of international groups are minimal, negligible and with the loss of threats, their own importance is lost as well. Another opinion says that the international organizations, as they are preventing the conflicts, they are, at the same time, fostering a strong collaboration between the parties. Surveying those above, we can state that due to the different strength and interests of the countries, all opinions have truth in them, thus we can say that the truth about the collaboration of international institutions is a blend of opinions.

The main and determinative party of today's international relations is the country. The foundation of an organic relationship among the countries has given rise to the need of the possibility for institutional activities over national borders. Thus the countries created international institutions via international agreements. These units are to be taken as the new elements of the international system, which help not only treating the conflicts but also the collaboration and interests among the countries and the occuring synergy effects can be utilised at the maximum. That is why communication and collaboration acquires a more and more important role in our globalising world, as through these institutions not only the national but also the regional and global influences can be reached as well.

The main purpose of the fight against money laundering is to prevent the legalisation of profits from different illegal crimes and returning that money into the legal/illegal economy, and collecting informations on the basic crimes and the criminals as well. For achieving this, the law enforcements_constantly collaborating with other countries and international institutions_-analising, using, mobilising and monitoring every possibility given by the law that help prevent the installation or exchange of illegal profits, that is to say: prevent money laundering. As the legalisation of dirty money is mainly taking place on international level — through national borders, overarching continents - the fight against it is only possible on an international level. For a possible outcome not only organized collaboration but also requirements for internal laws of countries are needed as well, meeting the standards and making it technically and professionally possible for the law enforcements to execute their duties. [3: 79] Furthermore, it is necessary to constantly develop the effectiveness of the national legislation, law enforcement and jurisdiction.

The institutions of the EU against money laundering had the first milestone at the end of the $20^{\text {th }}$ century which was later on followed by several international conventions and agreements. 


\section{The Recommendation of the European Commission}

The above properly confirm the need of regulations. The basis of this was the recommendation of the Committee of Ministers of the European Commission about preventing "the transfer of funds of criminal origin from one country to another and the process" accepted on 27 June 1980. [4] The initial European community intention was caused by the basically changed, more organized and violent attitude of crime that could be more and more felt in the member countries. For legalising the illegally acquired money taken with increasingly new types of crimes, the criminals started using the everyday bank system more often, taking advantage of its initial unregulated system. The recommendation-besides the detective organizations - focused on financial and credit institutions which had to scan the clients and worked as a preventive filter as well during the cash flow. ${ }^{3}$

\section{United Nations: Vienna Convention/Agreement}

The Agreement—originally called United Nations Convention against Illicit Traffic in Narcotic Drugs and Psychotropic Substances that was commonly known as the Vienna Convention or Vienna Agreement-created under the aegis of the UN on 20 December 1988 was signed by 67 countries of the world. ${ }^{4}$ [5] It took almost two years for it to become international law in August 1990 - after placing the $20^{\text {th }}$ ratificaion charter-and came into force on 11 November 1990. The purpose of the Convention (consisting of 34 chapters) was for the ratificational parties to stand against the crimes commited with drugs and psychotropic substances and the income of these illegal profits in a more organized and effective way. [6: 547] To reach the goals, measures were used concerning the previously strictly used banking secrecy in as much that they were declassified, thus the parties were obliged to give information to each other - based on judicial or other authorizing enactments - and they could not decline to do this referring to banking secrecy. The Agreement in Article 3, 5 and 7 focused on the fight against money laundering calling it a harmful thus indictable and punishable activity, and ordaining the fullfillment of overall legal aids according to this and the identification of devices used, monitoring the illegally acquired properties and the impounding, immobilisation and sequestration of such incomes. As for the collaboration, these activities are to be done co-operatively with other countries, mutually helping each other out. $^{5}$

3 According to this the law obliged the bank system to: 1) Identification of clients for account opening, renting safes, and cash transactions over limit. 2) Use of safes is available for clients graded as reliable. 3) Impounding banknotes related to crimes according to serial number. 4) The professional training of banking staff. Furthermore, the national and international collaboration was specified among banks and authorities and a system that helps the monitoring and comparison of banknotes during depositions.

4 Hungary joined the Vienna Convention on $22^{\text {nd }}$ August 1989, when signing the New York agreement.

5 For the mutual co-operation, the parties, in case of seizing illegal properties may share it and offer for the national and international organizations to be used for their work. 


\section{Basel Committee on Banking Supervision: Basel Statements}

The Basel Statements, elaborated by the swiss Basel Committee on Banking Supervision in December 1988 was regulating the practice of bank monitoring as well as the use of banking system for prevention of money laundering, which was signed by representatives of ten countries-United States of America, Belgium, United Kingdom, France, the Netherlands, Japan, Canada, Federal Republic of Germany (FRG), Italy, Sweden-and has been ratified in several countries. [7] The Statements among others was looking for a solution-as the banks and banking systems are organic parts of the financial world, thus they cannot prevent being partners directly or indirectly in money laundering - for the banking system and the authorities as their supervising systems to have principles that can prevent the banks and financial systems to take part in money laundering, keeping them to be trusted. The principles focused on identifying the clients, meeting the requirements and keeping the laws, the collaboration with the authorities and finally joining the Principles Statement. To create the related roles and internationally accepted standards-paralel with the role of national supervising institutions - the conditions of communication and co-operations had to be created, making a client-scanning system which can filter the risky and/or illegal financial transactions. The so-created preventively functioning financial monitoring system was not obligatory but a guidance for parties taking part in international financial life. The above is illustrated by Part 6 of the Statements, which confirms the attitude norms, thus: „....whatever the legal position in different countries, the Committee considers that the first and most important safeguard against money laundering is the integrity of banks' own managements and their vigilant determination to prevent their institutions becoming associated with criminals or being used as a channel for money laundering. The Statement is intended to reinforce those standards of conduct." [7: 2]

\section{European Commission: Strasbourg Convention}

The Convention 141/1990 of the European Commission signed 8 November 1990 was about "Laundering, Search, Seizure and Confiscation of the Proceeds from Crime." [8] Part of the direct preludes was an impact study created with the help of experts that was made to measure how well the actual international criminal collaborations and agreements in effect covered the regulations against the money laundering back then. [2: 36] The examination came to determine that the money laundering is an individual and far-reaching source of danger, so a new Agreement will be needed to be placed on totally new basis. According to this the Strasbourg Convention, as a theoretical guideline, is using the following principles:

- Vienna Agreement;

- the need of national regulations on money laundering;

- the undertaking of law aids relating money laundering;

- the authorities of countries financially interested in law aid;

- the question of law harmonization. 
The Agreement containing only recommendations and no obligatories emphasises the need of international collaboration and determined directives that can be efficiently used in international acts against money laundering. In case of illegal incomes, the Agreement highlighted the need of the parties to acknowledge and execute the other party's requests based on decree related to confiscation of property, except it does not count as a crime in the other party's laws, or the nation state does not give legal possibility. Given this, the money laundering was titled as crime and defined its illegal scope of activities that need special attention:

- conversion and transfer of possessions from crimes;

- dissembling and hiding original source of illegally acquired properties;

- stealing values of criminal sources;

- supporting and taking part in crimes specified in the Convention.

\section{Directive I of the European Union}

After realising the worsening effects of money laundering and organized crimes built around it, the European Union-using the Vienna Convention, Basel Statements, Strasbourg Convention and the 1980 Recommendation of the European Committee and their internal needs-joined the fight against money laundering and created the Council Directive 91/308/ EEC on prevention of the use of the financial system for the purpose of money laundering which was commonly known as the Directive I of the European Union. [9] Besides the above reasons, an emphasised role in the creation was that the previous international agreements were not in harmony with the needs and interests of the member countries and were not obligatory. For the EU members the obligatory Directive-besides harmonizing the law systems-determined the following goals:

- preventing the criminals taking part in money laundering to financially act against the market of the Union;

- the operation of free, internal market of the member countries needs to be harmonized with the measures against money laundering;

- in favor of increasing the effectiveness the European Union has to take active part in the fight against organized crime.

The Directive obligated the banks and financial institutions and other companies suitable for money laundering to identify their clients and over a particular limit (15 thousand ECU $)^{6}$ the clients are deemed to certify their identities. The generated informations and any suspicious activity related to money laundering had to be transmitted to the Financial Intelligence Unit (FIU) ${ }^{7}$

\section{United Nations: International Money Laundering Information Network}

Ten years after the 1988 Vienna Convention the United Nations founded the International Money Laundering Information Network (IMoLIN) which took a main role in the fight

\footnotetext{
6 The ECU was the currency of the European Community, and the later European Union between 1979 and 1999, before the introduction of the Euro.

7 The main goal of FIU was to foster, ensure and develop the communication between the members.
} 
A. BUGYÁKI: Milestones in the Foundation and Role of the Most Significant...

against money laundering, and together with the international institutions they elaborated a safe internet-based legislational and regulational information network (database, electronic library, calendar of events), thus giving access to up-to-date informations and effective help for the members. [10]

\section{United Nations: The Global Program against Money Laundering}

The United Nations Office on Drugs and Crime (UNODC) published The Global Program against Money Laundering (GPML) in 1998 to prevent laundering money from crimes and financing terrorism. [11] The program gave professional help, training and means to actualise these, where the fight against crimes related to money laundering was still backward.

\section{Joint Action of the Council: 98/699/JHA}

The Council accepted on 3 December 1998 the Joint Action adopted by the Council on the basis of Article K.3 of the Treaty on European Union, on money laundering, the identification, tracing, freezing, seizing and confiscation of instrumentalities and the proceeds from crime. This program contains: [12] [13]

- besides the termination of reservations, it gave legal possibility of seizing illegal possessions;

- the European Justice Network created a description to identify, trace, freeze, seize and confiscate illegal possession and means, which helped the informing and detection;

- the member countries during the procedures treated the requests of country members as that of an equal;

- collaboration was urged per the collaborational agreements;

- the member countries had to do every means necessary to prevent the cover-up of possession, unless it was forbidden in their internal laws;

- the member countries provided the authorities with the effective collaborative methods to identify, trace, freeze, seize and confiscate illegally acquired possessions and means.

\section{European Commission Conclusions, Tampere}

The European Commission's session on 15-16 October 1999 in Tampere defined the conclusions which approved the principle of mutual recognition both in civil and in criminal cases based on the justice authorities' verdicts and decrees, thus making the basis of the member countries' justice collaboration, the concept of freedom, safety and legal region. [14] Chapter $\mathrm{X}$ of the conclusions was about the special measures against money laundering, especially since money laundering is the main driving force of organized crime, thus - taking the Strasbourg Agreement and FATF recommendations into account—it is necessary to take every legal step with the harmonization of laws and information-flow, that is focused on the identification, tracing, freezing, seizing and confiscating the illegal possessions. For the goals to be reached, it was necessary to extend the limit of the power of Interpol to several crimes related to money laundering, and in the interests of increased transparency, within the confines of collaboration and law aid agreements, the possibility needs to be ensured for third countries to be able to trace illegal money. 
A. BUGYÁKI: Milestones in the Foundation and Role of the Most Significant...

\section{Wolfsberg Group}

The purpose of the Wolfsberg Group ${ }^{8}$ - now consisting of $13^{9}$ international banks, founded by the initiation of the greatest Swiss bank, UBS AG, on 30 October 2000-is to develop and show guidance preventing the international financial crimes and risks, especially on know-your-client (KYC), money laundering and terrorism. [15] The recommendations_-also called Wolfsberg anti-money-laundering principles - filtering money laundering, elaborated by the organization working on non-government basis are not obligatory, but due to the vocation of the members, these recommendations are met as basic conditions. The group elaborated an anti-laundering questionnaire ${ }^{10}$ for the members, which was used as a scanner for the financial service companies. After the terror attacks in New York, the main focus of the group is financing the fight against terrorism.

\section{United Nations: Palermo Agreement}

Within the confines of the United Nations, on 14 December 2000, in Palermo (Italy) the United Nations Convention against transnational organized crime was elaborated. [16] It is a milestone, as it was the first harmonized UN-action against organized crime. According to the convention, the organization's almost 200 members stand up harmonized against organized crime, corruption and money laundering. Besides the information-flow, for a wide justice collaboration, the followings were elaborated:

- law proceedings have been simplified, among others seizing possessions;

- the members are obliged to create their own Financial Information Units;

- the money laundering of illegally acquired possessions is expressed as crime;

- witness protection is accounted.

\section{Council Decision: 2000/642/JHA}

The European Union Council accepted on 17 October 2000 the concerning arrangements for cooperation between financial intelligence units of the Member States in respect of exchanging information, 2000/642/JHA Decision, which regulated the direct and effective co-operation among the obligatorily founded Financial Information Units. [17]

\section{Council Framework Decision: 2001/500/IB}

The 2001/500/IB: Council Framework Decision signed on 26 June 2001 elaborated on money laundering, the identification, tracing, freezing, seizing and confiscation of instrumentalities and the proceeds of crime. [18] This framework decision was the further reflection of the

\footnotetext{
8 The name of the group derives from the castle of Wolfsberg, where the foundation agreement was signed.

9 Besides the 11 founding banks (Banco Santander, Bank of Tokyo-Mitsubishi UFJ, Barclays, Citigroup, Credit Suisse, Deutsche Bank, Goldman Sachs, HSBC, JP Morgan Chase, Société Générale, UBS Banks), later on the Standard Chartered Bank and the Bank of America joined as well.

10 The Wolfsberg Group’s anti-laundering quiestionnaire contained questions from general to risk management, know-your-client, transparency, transaction shadowing, and the professional qualification of the administrators.
} 
above mentioned 98/699/JHA Joint Action, which determined every conjunctive activity related to covering, hiding, using illegal possessions as a crime. The illegally acquired possession was determined as a legal-economical category, and in the future all illegally acquired possession exceeding one year of imprisonment was urged to be confiscated. The seizing and confiscating of illegal possessions directly or indirectly related to organized crime and assigned to third party could be realized much more effectively as the newly created concepts and regulations were put into practice.

\section{Directive II of the European Union}

The extended Directive 91/308/EEC on prevention of the use of the financial system for the purpose of money laundering - commonly known as Directive II of the European Union (Directive 2001/97/EC) — was signed on 4 December 2001 by the Union members. [19] The direct reason of creating the agreement was-besides the increasing number of crimes related to organized crime and the defense of the mutual European currency, the Euro-clearly a reaction to the terrorist attack in the United States of America on 11 September 2001. The extended Directive II — which has automatically overwritten the previous - adapted from the $40+9^{11}$ recommendations of Financial Action Task Force on Money Laundering (FATF), the Vienna Convention, realising the unregulated risks in the financial system, which could be used for financing terrorist attacks. Preventing the criminals to stay anonymous, client identification ${ }^{12}$ was obligatory in cases when a certain limit is reached. The new directive extended the material and personal extent of crimes related to money laundering. In the previous case, the use of providers' activities for money laundering is taken as preventive purpose and defined which attitudes count as money laundering, obligating the members to keep the prohibition of money laundering defined in the directive. [21: 7-8] With the extension of personal extent besides the financial providers, the partly ${ }^{13}$ or fully involved obliged people are accountants, auditors, lawyers, notaries, estate agents and tax consultants: such enterpreneur types that can be involved with the legalisation of illegally acquired money during their activities. Relating the credible client identification obligation, no specific method was defined, but it prescribed in which cases it must be done. ${ }^{14}$ Since there was no specific definition for the case of simplified or strict client scanning, only some cases were defined, the member countries could decide on their own about the strictness of the matter. An important milestone was a new provision about the disclosure prohibition, which—besides not defining

11 The FATF is an independent, government-related, specially authorised, particular and collaborative action group functioning under the Organisation for Economic Co-operation and Development (OECD), defining the strategy and main elements of the international fight against money laundering and financed terrorism. The workgroup has worked their recommendations in 40 points about the unified, internationally accepted basic system, which is not legally obligatory, but the countries accepting it are adjusting their national legislation to it, and it is essential for the international co-operation. FATF declared further 8 points in October 2001, and another in October 2004, totally 9 special points for the fight against financed terrorism, reacting to new types of dangers. [20]

12 The Directive stipulates that certain steps should be taken to find the real identity of the person in the backround in case it is doubtful that the client is not acting on its own behalf. However, the Directive does not determine who should be regarded as the real possessor.

${ }_{13}$ In case the providers do not provide direct financial services, the Directive defines partial regulations, meaning that they are obliged to notify their activity in particular cases only (e.g. real estate purchase).

14 Scanning is obligatory at the first meeting of the provider and client, in case of every transactions exceeding 15 thousand Euros, and in the smallest suspicion of money laundering. 
A. BUGYÁKI: Milestones in the Foundation and Role of the Most Significant...

exclusions - prohibited the providers to inform their clients if there was any notifications or data-forwarding towards the authorities about them. [22: 137-155]

\section{United Nations and the International Monetary Fund: Model Legislation}

The United Nations Office on Drugs Crime and collaborating with the International Monetary Fund ${ }^{15}$ published in $2003^{16}$ the Model Legislation on Money Laundering and Financing of Terrorism, in order to use international recommendations and practices to foster collaborating authorities' to create international standards. [23]

\section{Council of Europe: Warsaw Agreement}

The Council of Europe Convention on Laundering, Search, Seizure and Confiscation of the Proceeds from Crime and on the Financing of Terrorism has been signed in Warsaw on 6 May 2005. [24] The Agreement consisting of 7 chapters and 56 articles, besides increasing the international co-operation and its detailed legal regulations, focuses on increasing the efficiency, in which case all member country needs to create their own Financial Information Unit to "access directly or indirectly, on a timely basis to the financial, administrative and law enforcement information that it requires to property undertake its functions, including the analysis of suspicious transaction reports." [24] The Agreement detailed the special cases of declining the co-operation and emphasized that if the purpose of the crime is related to financing of terrorism, the data-providing cannot be denied.

\section{Council Framework Decision: 2005/212/IB}

Council framework decision on Confiscation of Crime-Related Proceeds, Instrumentalities and Property has been elaborated on 24 February 2005, generally disposes of confiscation of crime-related proceeds, as well as defines the possession surveillance and possession recovery. [25] As the previous, 2001/500/IB council framework decision's expectations about illegally acquired possessions exceeding 1 year of imprisonment to be confiscated in practice of member countries' collaborations, thus to increase efficiency, the authority of confiscating was exceeded to the range of the specific crime organizations ${ }^{17}$ and with inclusion of the fight against terrorism.

\section{Directive III of the European Union}

The Directive 2005/60/EK on the prevention of the use of the financial system for the purpose of money laundering and terrorist financing came into force on 26 October 2005 which is

15 The Washington-based international organization interested in global financial collaboration, stability of exchange rate and economic growth was founded in 1945.

16 The initial basis of Model legislation was founded in 1999 by The United Nations Office on Drugs Crime.

17 The crimes are the following: counterfeiting related to the introduction of the Euro; money laundering, the identification, tracing, freezing, seizing and confiscation of instrumentalities and the proceeds of crime; human trafficking; aiding illegal immigration and transmigration and illegal residing; sexual exploitation of children, child pornography; drug trafficking. 
the Direction III of European Union against money laundering and financing terrorism. [26] The leaders of member countries realised that, besides the increasing and more organized crimes, they have to focus not only on the illegally acquired money flowing into the financial system, but on the legal incomes too, because those are capable to be used for financing terrorism as well. The rethought Directive according to the above extended its effect besides the money laundering to fight against terrorism and preventing financing terrorism with taking the $40+9$ recommendations of FATF, in which case "...the purpose is not only preventing providers' activities for money laundering, but also preventing the support of terrorism via these activities or things that can be expressed with money." [22: 139-140] The Council gave two years (until 15 December 2007) for countries to apply these Directive. Besides the prevention (prohibition) of money laundering and financing of terrorism, the extended regulation system defines those criminal attitudes and activities which have the possibility of directly or indirectly fostering money laundering and the financing of terrorism. ${ }^{18} \mathrm{~A}$ new element is the risk-based approach which, for the purposes of preventing money laundering, determines a unified obligation of legislation, client scanning and monitoring. At the same time, it declares that the scale of risk in the case of money laundering and financing of terrorism, is not always the same, it may differ in specific cases, thus the directive gave the opportunity for member countries to use stricter or lighter proceedings. As for the client scanning — redressing the lack of Directive II—-we have much more definite criteria for identifying the clients and/or real possessors, and the measures for this activity, but the method of identification (e.g. the amount and types of data to record) is still up to member countries. ${ }^{19}$ Furthermore-realising the dangers of international corruption-the identification and definition of political persona has been involved in the directive as well. The Directive defined two categories in the aspect of risk-based client scanning. One is the simplified client identification which, in case of meeting specific requirements, gives alternate possibility for identifying low-risk clients and transactions, but in case of possible money laundering and financing terrorism, the identification is obligatory. The other is the obligation of client scanning in cases when the risk of money laundering and financing of terrorism is high, by its nature. ${ }^{20}$

An important milestone was-when specific requirements were met-the possibility of accepting of client scanning by other providers, aka third party, which was justified by the increased efficiency and faster investigation. As for the disposals of the disclosure prohibition - in spite of Directive II-exceptions have been determined; according to these the prohibition does not concern the disclosure of such transferred information, whose address-

18 The Directive refers not only to financial but also to non-financial sectors, e.g. to lawyers, notaries, real estate agents, gambling companies, trustee and group providers and all enterpreneurs which have cash-flow of at least 15 thousand Euros.

19 "The measures of client scanning are the following: identifying the client and checking the ID; in specific cases identifying the real possessor and creation of risk-based measures for identifying the IDs; gaining information on the goals and attitude of the financial relation; constant monitoring of the financial relation, meaning the scanning of transactions during the relation." [26: 23]

20 By their nature they mean greater risk, thus beside defining the concrete measures, the intensified client scanning is obligatory to be done in the following cases: if the client does not appear personally for identification; in the case of border-crossing relationships for correspondent banking with third country institutes; in the case of financial relationships with political personas residing in other member countries or in a third country. [26: 25-26] 
ees are authorities and law enforcements providing the supervision. ${ }^{21}$ Besides the above, the directive urges every member country to create their own Financial Information Unit to increase the efficiency of notificational obligation; besides collecting, analizing and transmitting information, these Units have the obligation of annual data providing. Furthermore, the directive declares the norms of collaborative professional training and sanctions, which sanctions need to be sufficiently effective, proportionate and retentive in case of contravention.

Related to Directive III, the following three later decrees are to be mentioned: [2: 59-60]

- 1 August 2006: Commission Directive laying down implementing measures for Directive 2005/60/EC of the European Parliament and of the Council as regards the definition of "politically exposed person" and the technical criteria for simplified customer due diligence procedures and for exemption on grounds of a financial activity conducted on an occasional or very limited basis; [27]

- 26 October 2005: Regulation (EC) No 1889/2005 of the European Parliament and of the Council on controls of cash entering or leaving the Community; [28]

- 15 November 2006: Regulation (EC) No 1781/2006 of the European Parlaiment and of the Council on information on the payer accompanying transfers of funds. [29]

\section{Directive IV of the European Union}

The European Parliament and Council accepted ${ }^{22}$ Directive 2015/849 on the prevention of the use of the financial system for the purposes of money laundering or terrorist financing, amending Regulation (EU) No 648/2012 of the European Parliament and of the Council, and repealing Directive 2005/60/EC of the European Parliament and of the Council and Commission Directive 2006/70/EC based on the recommendations of Financial Action Task Force on Money Laundering (FATF) on 20 May 2015 in Strasbourg, which is Directive IV of the European Union against money laundering. ${ }^{23}$ The purpose of the new Directive, besides increasing the efficiency against money laundering, tax crime and financing terrorism is to strengthen and harmonize the EU's anti-laundering regulations with international expectations. As its predecessors, the purpose of this Directive was to prevent using financial systems of the EU for money laundering, organized crime and financing terrorism, furthermore preventing illegally acquired possessions to constantly and uncontrollably flow into financial and economic sectors, as it may significantly weaken the stability, integrity and international judgement and development of EU member countries. In order to achieve these goals-besides raising criminal law to a unified EU level—it obliges member countries to stand stricly, purposefully and proportionally against crime in the aspect of both collaboration and execution as well. In the aspect of proportionality, it has been emphasized that in order

21 Since it doesn't result in disclosure, the disclosure of informations about the following providers are exceptions: institutes that are members of the same financial conglomerate; specific non-financial providers, if their activities are connected to the same legal person, or the activities are done in the same unit; in the case of financial and non-financial providers, if the client and affair is the same; if the specific non-financial provider tries to dissuade a client from illegal activity.

22 A decree has been accepted as well, at the same time with the Directive, related to monitoring financial transactions, with the purpose of making simple and effective the monitoring of financial transactions in the future with defining the monitoring and regulating the circle of data to be recorded by financial providers. This gives a major help for the authorities for the future supervision of the source and movement of money.

23 The Directive contains obligatory regulations for the member countries which have to be introduced until June 2017. [30] 
to protect society from crime, the member countries' regulations have to be in harmony with the stability and integrity of the EU's financial systems; furthermore, there should not be such obligations that are legally and financially disproportionate for the companies' activities. To increase the transparency, the Directive introduced new regulations deciding about the creation of a public, central EU database, which helps to identify the real possessors of companies, trustees and other legal entities. [31] Access to these databases is limitless and free of charge for specific Financial Information Units and authorities, but for other natural or legal entities access is granted only after proving legitimate interests, online registration and payment. ${ }^{24}$ The limitation of access to these databases is possible only "in exceptional circumstances, on occasional cases", but the emphasized public personas ${ }^{25}$ and their family members are under special jurisdiction in the aspect of fight against corruption. The obliged providers are to ask for required personal datas for keeping the records during the client scanning, then record these datas; after scanning these datas, suspicious transactions are to be reported.

Another purpose of the new Directive is the aspiration for unified and harmonized politics expected by member countries for those countries that are outside the EU in which regulations against money laundering and financing terrorism are not effective enough.

Today money laundering and financing terrorism is clearly global and transnational in nature, thus the Directive emphasizes the increasing importance of coordination and co-operation between the member countries' Financial Information Units, and the share of information in case of identifying and monitoring suspicious cash-flow. An important and expected requirement in the European Union has become the possibility of ensuring and monitoring all financial transactions; with this, informations not only about the owner but the information about the beneficiary have to be transmitted as well.

The previously recommended risk-based method ${ }^{26}$ — with this the specific cases of threats are to be taken care of according to their risk level-is obligatory to use in the future for the providers, thus terminating the earlier mechanical data recording. By introducing this, the regulations related to client scanning are getting stricter, and according to the new regulations about the use of data, the providers are obliged to check their datas on clients at least every five years. ${ }^{27}$

Under the aspect of the sanctions, it is an important change for the Directive to be extended to suspension of licence or deletion from registers, and identifying personal responsibility and suspending leadership or withdrawal of the initiative. Besides the above, the Directive disposes of maximum amount of fines; the amount of this is at least twice as much as the profit from the infringement, or at least 1 million Euros. [32] If the affected entity is a loan bank or financial institution, the maximal fine, in the case of legal entity, is 5 million Euros at least, or $10 \%$ of the yearly income; in the case of natural persons the fine is a maximum of 5 million Euros.

Besides the tightenings, a lightening of specific level is the possibility of the new Directive is handing in the ownership statement via electronic way-with meeting specific expecta-

24 Member countries are given permission to operate public registers.

25 Emphasized public personas are: heads of states, cabinet members, judges of the Supreme Courts and Members of Parliaments.

26 Identified threats can be treated most efficiently with risk-based approach (RBA), with which a comprehensive and fact-based, purposeful approach can be used.

27 With the introduction of risk-based approach the client-scanning can be conducted in a simplified, normal or intensified procedure. 
tions - instead of the earlier exclusive possibility, when client identification was possible in person, with handing over the authenticated copy of IDs.

With the extension of the Directive, the previous 15 thousand Euros limit is decreased to 10 thousand Euros of cash payment, which is to be used-with extending the vendors' circle-in the cases of commodity merchants and gambling organizers.

As the above shows, several useful changes have been made, but it was soon to be found out that in some areas, further and immediate measures are needed; thus, in December 2015 the EU laws focusing on the fight against money laundering and financing terrorism have been revised and confirmed. The elaborated recommendation of the above has been published on 5 July 2016 by the European Commission; the most important modifications are the following: [33]

- treating the threats of financial transactions via new technologies and virtual currencies;

- the moderation of risks related to non-registered, prepaid devices;

- the increase and harmonization of monitoring and client-scanning of suspicious financial transactions related to high-risk third countries;

- extending the range of Financial Information Units, and ensuring the limitless and immediate access of information;

- confirming transparency.

Transparency is expected to improve with the recommended modifications put in practice, which increases the detection of law enforcement authorities related to the areas of money laundering and financing terrorism as well.

\section{Conclusion}

As it has been demonstrated, a long and difficult way lead to the foundation and actual situation of international organizations fighting against money laundering-and organized crime, financing of terrorism — in which primarily, besides the European Union (European Communities), the International Monetary Fund and the Organisation for Economic Co-operation and Development took and still takes active part. As Directive I of the European Union defined the money laundering in the aspect of crime related to drugs and defined obligations for financial sector only, the Directive II extended its effect to the cases of professions and activities as well. Directive III following the previous road, used the provisions of FATF extended to financing of terrorism, and is more focused on client scanning and introduced the risk-based approach; the realization of this latter in practice is still in progress. Going along this same path, Directive IV, for increasing transparency and repelling corruption, besides introducing the central EU database, focused on obligating the risk-based approach of client-scanning, and creating a more unified and harmonized policies both among the member countries and third countries.

The mission of international organizations founded against money laundering and financing terrorism is to stop legalization and use of money derived from crimes, and to stand against the financial support of terrorism by instituting effective and standardized measures. The leaders of the world realized that for the effective fight it is not enough to use legal means only; for the success it is necessary to have an extended, harmonized and strong international collaboration and co-operation. The signed international agreements and the standardised 
legal regulations and the increasing number of committed countries show us that the world is on the right track to achieve this. The problem is, being an international challenge, an international solution would be expedient, but many countries still are not committed to any such organizations; the reason of this is that the countries cannot or are unwilling to meet the requirements, thus giving up their economical and political interest, and their own sovereignity. For successful actions an international concensus is needed as well-even if it means introducing political and/or economic retaliations and sanctions-which could possibly strenghten the future role and effect of international organizations. For reaching the goals - as one of the basis of the fight against money laundering is reaction to the criminal methods with following and post factum legislation-it is necessary to introduce regime measures, including creating flexible legal and institutional backing, and at the same time setting up professional training of financial detectives taking part in the workflow. In addition to the above it is necessary to focus on the further communal sharing of acquired information, thus stepping over the limits of nation states, raising it to a unional (international) level, whereby more significant results could be reached. To sum up, we identify the rejoice due to the increasing number of committed members of international organizations, but at the same time the quality of co-operation and communication have to improve significantly. And finally, let me state another important remark. If merely a fraction of the huge fortunes deriving from money laundering - which, according to a rough estimate could reach more than a thousand billion dollars annually [34] — could be confiscated by increasing the efficiency, this substantial amount could be directly spent on fighting crime...

\section{References}

[1] BLAHÓ A., PRANDLER Á.: Nemzetközi Szervezetek és Intézmények. 2. átdolg. kiad. Budapest: Aula Kiadó, 2005.

[2] PINTÉR B.: A pénzmosás elleni küzdelem az új magyar büntetőjogban. (PhD-értekezés) Pécs: Pécsi Tudományegyetem, Állam- és Jogtudományi Kar, 2012.

[3] CECH A., SZŰTS M.: A pénzmosás elleni küzdelem nemzetközi követelmény-rendszere és a magyar jog(szabályok). Külgazdaság, 6 (2003), 77-92.

[4] Recommendation No. R (80) 10 of the Committee of Ministers to Member States on Measures against the Transfer and the Safekeeping of Funds of Criminal Origin. Strasbourg: Council of Europe, Committee of Ministers, 27 June 1980. https://rm.coe.int/CoERMPublicCommonSearchServices/ DisplayDCTMContent?documentId=09000016804f6231 (Downloaded: 28.01.2017)

[5] United Nations Convention. Against Illicit Traffic in Narcotic Drugs and Psychotropic Substances. New York: UN, 1988. http://unodc.org/pdf/convention_1988_en.pdf (Downloaded: 31.01.2017)

[6] CHAPPEZ, J.: La lutte internationale contre le Blanchiment des capitaux d'origine illicite et le financement du terrorisme. Annuaire Français de Droit International, 49 (2003), 542-562.

[7] Prevention of Criminal Use of the Banking System for the Purpose of Moneylaundering. Basel: BaselCommittee on Banking, 1988. http://secure.kesdee.com/ksdlms/courseimports/ Product_424/CourseLibrary/BaselRecommendationsandRBICirculars/pages/ BaselStatementOfPrinciples.pdf (Downloaded: 03.02.2017) 
A. BUGYÁKI: Milestones in the Foundation and Role of the Most Significant...

[8] Convention on Laundering, Search, Seizure and Confiscation of the Proceeds from Crime. European Treaty Series, 1418 XI (1990). https://rm.coe.int/CoERMPublicCommonSearchServices/DisplayDCTMContent? documentId=090000168007bd23 (Downloaded: 01.02.2017)

[9] Council Directive on Prevention of the use of the Financial System for the Purpose of Money Laundering (91/308/EEC). Luxemburg: Official Journal of the European Communities, 1991. http://eur-lex.europa.eu/legal-content/EN/TXT/ PDF/?uri=CELEX:31991L0308\&from=HU (Downloaded: 28.01.2017)

[10] International Money-Laundering Information Network. www.imolin.org/imolin/en/about_ us.html (Downloaded: 02.02.2017)

[11] Objectives of the Global Programme against Money-Laundering, Proceeds of Crime and the Financing of Terrorism. UNODC,1998. www.unodc.org/unodc/en/money-laundering/ programme-objectives.html (Downloaded: 02.01.2017)

[12] Joint Action 98/699/JHA of 3 December 1998. European Judicial Network, Judicial Library. www.ejn-crimjust.europa.eu/ejn/libcategories.aspx?Id=76 (Downloaded: 02.01.2017)

[13] GÁL I. L.: A pénzmosás. Budapest: KJK-Kerszöv Jogi és Üzleti Kiadó, 2004.

[14] Tampere European Council. Presidency Conclusions. 15 and 16 October 1999. In. Az Európa Tanács következtetései (1993-2003). www.consilium.europa.eu/hu/europeancouncil/conclusions/1993-2003/ (Downloaded: 30.01.2017)

[15] The Wolfsberg Group. www.wolfsberg-principles.com/ (Downloaded: 01.02.2017)

[16] United Nations Convention against Transnational Organized Crime. Palermo, 14 December 2000. http://net.jogtar.hu/jr/gen/hjegy_doc.cgi?docid=A0600101.TV (Downloaded: 01.02.2017)

[17] Counsil Decision Concerning Arrangements for Cooperation between Financial Intelligence Units of the Member States in Respect of Exchanging Information (2000/642/JHA). Official Journal of the European Communities, 2410 (2000). http://eur-lex.europa.eu/LexUriServ/ LexUriServ.do?uri=OJ:L:2000:271:0004:0006:EN:PDF (Downloaded: 01.02.2017)

[18] Council Framework Decision on Money Laundering, the Identification, Tracing, Freezing, Seizing and Confiscation of Instrumentalities and the Proceeds of Crime. Official Journal of the European Communities, 507 (2001). http://eur-lex.europa.eu/legal-content/EN/TXT/ PDF/?uri=CELEX:32001F0500\&from=hu (Downloaded: 02.02.2017)

[19] Directive 2001/97/EC of the European Parliament and of the Council. 4 December 2001. http://eur-lex.europa.eu/legal-content/EN/ALL/?uri=CELEX:32001L0097 (Downloaded: 02.02.2017)

[20] History of the FATAF. www.fatf-gafi.org/about/historyofthefatf/ (Downloaded: 31.01.2017)

[21] MURRAY, K.: The Uses of Irresistible Inference: Protecting the System from Criminal Penetration through more Effective Prosecution of Money Laundering Offences. Journal of Money Laundering Control, 14 (2011), 7-15. DOI: https:// doi.org/10.1108/13685201111098842

[22] PAPP Zs.: Az Európai Unió pénzmosás elleni második és harmadik irányelvének eltérő rendelkezései. Iustum Aequum Salutare, IV 1 (2008), 137-155.

[23] Model Legislation on Money Laundering and Financing of Terrorism. UNODC-IMF. 1 December 2005. www.imf.org/external/np/leg/amlcft/eng/pdf/amlml05.pdf (Downloaded: 01.02.2017) 
A. BUGYÁKI: Milestones in the Foundation and Role of the Most Significant...

[24] Council of Europe Convention on Laundering, Search, Seizure and Confiscation of the Proceeds from Crime and on the Financing of Terrorism. Varso, 16 May 2005. http://net. jogtar.hu/jr/gen/hjegy_doc.cgi?docid=A0800063.TV (Downloaded: 02.02.2017)

[25] Council Framework Decision 2005/212/JHA on Confiscation of Crime-Related Proceeds, Instrumentalities and Property. 24 February 2005. http://eur-lex.europa.eu/legal-content/EN/ TXT/PDF/?uri=CELEX:32005F0212\&from=HU (Downloaded: 31.01.2017)

[26] Directive 2005/60/EC of the European Parliament and of the Council on the Prevention of the Use of the Financial System for the Purpose of Money Laundering and Terrorist Financing. 26 October 2005. http://eur-lex.europa.eu/legal-content/EN/TXT/ PDF/?uri=CELEX:32005L0060\&from=HU (Downloaded: 01.02.2017)

[27] Commission Directive Laying down Implementing Measures for Directive 2005/60/EC of the European Parliament and of the Council as Regards the Definition of 'Politically Exposed Person' and the Technical Criteria for Simplified Customer Due Diligence Procedures and for Exemption on Grounds of a Financial Activity Conducted on an Occasional or Very Limited Basis. 1 August 2006. http://eur-lex.europa.eu/legalcontent/EN/TXT/ PDF/?uri=CELEX:32006L0070\&from=HU (Downloaded: 31.01.2017)

[28] Regulation (EC) No 1889/2005 of the European Parliament and of the Council on Controls of Cash Entering or Leaving the Community. 26 October 2005. http://eur-lex.europa.eu/legal content/EN/TXT/PDF/?uri=CELEX:32005R1889\&from=HU (Downloaded: 31.01.2017)

[29] Regulation (EC) No 1781/2006 of the European Parlaiment and of the Council on Information on the Payer Accompanying Transfers of Funds. 15 November 2006. http:// eur-lex.europa.eu/legal-content/EN/TXT/PDF/?uri=CELEX:32006R1781\&from=HU (Downloaded: 31.01.2017)

[30] Directive (EU) 2015/849 of the European Parliament and of the Council on the Prevention of the Use of the Financial System for the Purposes of Money Laundering or Terrorist Financing, Amending Regulation (EU) No 648/2012 of the European Parliament and of the Council, and Repealing Directive 2005/60/EC of the European Parliament and of the Council and Commission Directive 2006/70/EC. 20 May 2015. http://eur-lex.europa.eu/legal-content/EN/ TXT/PDF/?uri=CELEX:32015L0849\&from=HU (Downloaded: 30.01.2017)

[31] FAJCSÁK G.: Offshore riadó!-Az EU döntése nyomán átlátható lesz a vállalkozások tulajdonosi köre. 21 July 2015. http://rsm.hu/blog/2015/07/offshore-riado-az-eu-dontesenyoman-atlathato-lesz-a-vallalkozasok-tulajdonosi-kore (Downloaded: 14.01.2017)

[32] Pénzmosás: Szigorúbb szabályokat hagyott jóvá a Tanács. 20 April 2015 http://consilium. europa.eu/hu/press/press-releases/2015/04/20-money-laundering-strengthened-rules/ (Downloaded: 14.01.2017)

[33] Proposal for a Directive of the European Parliament and of the Council Amending Directive (EU) 2015/849 on the Prevention of the Use of the Financial System for the Purposes of Money Laundering or Terrorist Financing and Amending Directive 2009/101/EC. Commission staff working document executive summary of the impact assessment. Strasbourg, 5 July 2016. http://eur-lex.europa.eu/legal-content/EN/TXT/ PDF/?uri=CELEX:52016SC0224\&from=HU (Downloaded: 14.01.2017)

[34] Világgazdaság: Új fegyverek a pénzmosás ellen-Számos IT-megoldás létezik az illegális tranzakciók kivédésére. 28 October 2011. https://vg.hu/vallalatok/infokommunikacio/ujfegyverek-a-penzmosas-ellen-361253/ (Downloaded: 14.01.2017) 